\title{
BROADBAND ACCESS TECHNOLOGIES EVALUATION TOOL (BATET)
}

\author{
João Paulo Ribeiro Pereira ${ }^{1}$, José Adriano Pires ${ }^{2}$ \\ Technological School of Polytechnic Institute of Bragança, Apartado 134, Bragança, Portugal

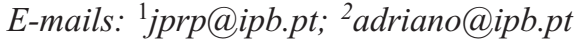

Received 22 March 2007; accepted 17 Dec 2007

\begin{abstract}
The goal of this paper is to identify all the essential costs of building broadband access networks, and then to comparise different technologies in various scenarios. Different market segments (Scenarios) have different geographical characteristics and will require different amounts of access bandwidth. These different market segments will be served by alternative access technologies that minimise overall costs. In order to do this, we have developed a model framework and an evaluation tool.

To measure the attractiveness of several broadband access technologies, the proposed tool compares the costs, revenues, NPV, IRR, payback periods etc for 3 scenarios. The paper presents a techno-economic analysis of 8 broadband technologies for access networks: digital subscriber line (DSL), hybrid fibre coax (HFC), power line communications (PLC), fibre to the home (FTTH), fibre to the curb (FTTC), fibre to the cabinet (FTTCab), and wireless alternatives such as WiMAX and satellite.
\end{abstract}

Keywords: access networks, broadband access technologies, cost model.

\section{Introduction}

Access to ICT as a development tool for society is recognised as a political, economic and social issue of high importance [1]. One of the factors mitigating this digital division is a broadband access, not only in urban areas, but also in rural and developing areas. Building telecommunications networks in rural areas is costly and in many cases there is not a good commercial business for rural deployments [2]. In most rural areas low population density and high deployment costs discourage private investments, creating a negative feedback of limited capacity, high prices, and low service demand.

An access network infrastructure must be established for delivery of a complex mix of broadband services like fast Internet access, telecommuting, and video on demand on a market of great demographic diversity [3]. Actually, residential broadband access is mainly used for high-speed Internet and telephony services. The requirements for higher access capacities are primarily driven by the increasing use of several broadband user terminals in the home and introduction of live TV streaming.

The digital society increased the rapid bandwidth demand that put pressure on the network. Although national networks are largely upgraded to cope with this demand, a bottleneck remains over the 'last (or first) mile' between the customer and the first node in the network. The residential access network infrastructure remains one of the major obstacles to the deployment of a broadband telecommunications network. The pre-existing telecommunications infrastructure is generally poor and unevenly distributed in favour of urban centres [4].

The methodology and tool presented in this paper has been developed to evaluate the most relevant broadband access technologies. These solutions include xDSL, HFC, PLC, FTTH, FTTC, FTTCab, and wireless alternatives such as WiMAX and satellite.

This paper identify all the essential costs of building access networks, and perform a detailed comparison of the different broadband access technologies in several scenarios.

Different market segments (Scenarios) have different geographical characteristics and will require different amounts of access bandwidth. These different market segments will be served by alternative access technologies that minimise overall costs. We consider a scenario as the description of a network situation to provide a given service to a number of users within a certain area and during a study period (10 years). 
To measure the attractiveness of the several broadband access technologies, the proposal tool compares the costs, revenues, NPV, IRR, payback periods etc for the 3 scenarios.

\section{Broadband Access Technologies}

Access network refers to the network between the Distribution/Regional network and the subscriber (Fig 1). The local access network is also often referred to as "the last mile" and "the local loop". The access network remains a bottleneck in terms of the bandwidth and service quality it affords the end user. The last mile problem has impeded the growth of broadband services and applications.

Access networks are usually the most expensive component in terms of capital investment and ongoing cost of maintenance and repair [5]. The access network is much more spread geographically and covers larger areas. The available capacity on access lines is modest with respect to availability in aggregation/distribution and core parts of the network [6]. The capacity of the access network to delivery broadband services remains as a challenge ("last mile problem").

Some of the most important last-mile solutions include xDSL, HFC, FTTH, PLC, WiMAX, Satellite etc. The selection of the best solution requires understanding the technical possibilities and limitations of the different alternatives, as well as understanding the costs resulting from building and operating the networks.

The choice of access technology depends on various variables like demography and geography. Others important variables are [7]: number of subscribers; clients dispersion and service area; existing infrastructures; network architecture (wireline, wireless or hybrid); services to support (like voice, data and video) and associated bit rate; geographic characteristics; infrastructure costs; labour cost; operation costs; and access costs.

Our tool calculate the cost of the access part of the network, and we define the network starting from a central office (or head end, LV transformer substation, base station etc) node and ending at the subscriber CPE. At the CO node, our model framework consider only the devices that support the connection to the access network side (like OLT, DSLAM etc), and do not include the equipment that support the link to the distribution/regional network (such router etc).

\section{Tool proposal}

There are different network architectures that provide varied levels of service to the customer. Each architecture differs in complexity, network functionality, services supported and overall network costs.

The network architectures and technologies will vary by cost, risk, flexibility, scalability, complexity and time to market considerations. It was argued in that the most criti-

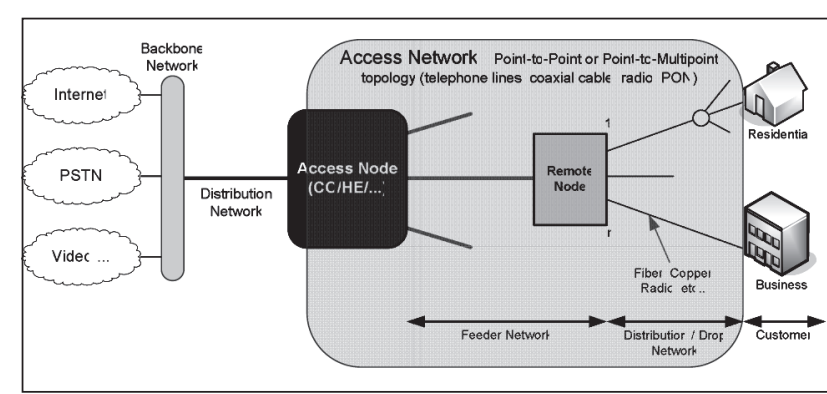

Fig 1. Generic access network model

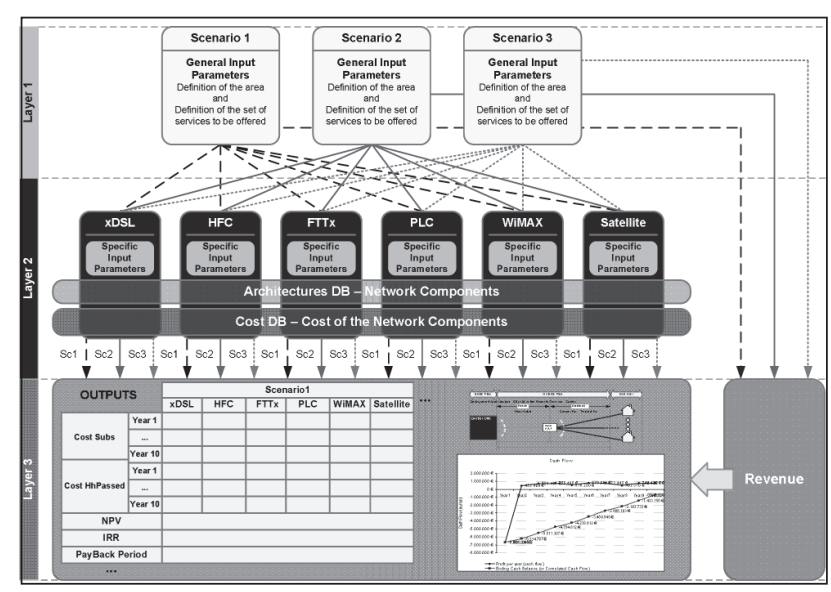

Fig 2. Tool architecture (layers)

cal parameters to include in a techno-economical model for broadband systems are subscriber density, civil works configuration, component cost evolution, and demand assessment (service penetration).

The model framework illustrated in Fig 2 is the basis of our tool. The tool has 3 main layers (Fig 2): General Input parameters (Layer 1); Processing (Layer 2) and Outputs (Layer 3).

\subsection{General input parameters (Layer 1)}

As we have seen above, the definition of the Input attributes is fundamental to obtain the right outputs. The area definition: Selection of the geographical area; Customer segments to be served; and Existing network infrastructure situation. The definition of the set of services to be offered: Services to be provided; Bandwidth; Service definitions for each user segment with adoption rates and tariffs.

The model divides the inputs into 2 main categories: general and specific input parameters (Layer 2). General parameters are those that describe the area and service characteristics and are common to all the technologies (Table 1). The specific parameters are those that characterise each solution, in technological terms (described in the next section).

Each technology type has elements that are dedicated as, for example, modems and shared elements (shared by 
Table 1. General Input Parameters (for 3 scenarios)

\begin{tabular}{|c|c|c|c|c|c|c|}
\hline \multirow[b]{2}{*}{$\begin{array}{l}\text { Area } \\
\text { characteristics }\end{array}$} & \multicolumn{2}{|c|}{ Scenario 1} & \multicolumn{2}{|c|}{ Scenario 2} & \multicolumn{2}{|c|}{ Scenario 3} \\
\hline & Value & $\begin{array}{c}\text { Trend } \\
(\% \\
\text { per } \\
\text { year }) \\
\end{array}$ & Value & $\begin{array}{l}\text { Trend } \\
(\% \\
\text { per } \\
\text { year })\end{array}$ & Value & $\begin{array}{c}\text { Trend } \\
(\% \\
\text { per } \\
\text { year }) \\
\end{array}$ \\
\hline $\begin{array}{l}\text { Geographical area to } \\
\text { be covered }\left(\mathrm{km}^{2}\right)\end{array}$ & 10 & 0,0 & 20 & 0,0 & 50 & 0,0 \\
\hline $\begin{array}{l}\text { Total numb of } \\
\text { potencial subscribes } \\
\text { (homes passed) }\end{array}$ & 1500 & 1,5 & 5000 & 1,5 & 10000 & 1,5 \\
\hline $\begin{array}{l}\text { Technology } \\
\text { penetratiom rate } \\
\text { (expected market } \\
\text { penetration) } \\
\end{array}$ & $70 \%$ & 2,0 & $60 \%$ & 2,0 & $45 \%$ & 2,0 \\
\hline $\begin{array}{l}\text { Number of } \\
\text { subscribers }\end{array}$ & 1050 & & 1050 & & 1050 & \\
\hline $\begin{array}{l}\text { Subscribers density } \\
\text { per } \mathrm{km}^{2}\end{array}$ & 105 & & 105 & & 105 & \\
\hline $\begin{array}{l}\% \text { of single family } \\
\text { houses }\end{array}$ & $80 \%$ & 0,0 & $20 \%$ & $0,0 \%$ & $10 \%$ & 0,0 \\
\hline $\begin{array}{l}\text { \% of apartment } \\
\text { building }\end{array}$ & $20 \%$ & 0,0 & $80 \%$ & $0,0 \%$ & $90 \%$ & 0,0 \\
\hline $\begin{array}{l}\text { Average number of } \\
\text { floors per building }\end{array}$ & $3 \%$ & 0,0 & $7 \%$ & $0,0 \%$ & $10 \%$ & 0,0 \\
\hline $\begin{array}{l}\text { Average number of } \\
\text { living units per floor }\end{array}$ & $2 \%$ & 0,0 & $3 \%$ & $0,0 \%$ & $4 \%$ & 0,0 \\
\hline $\begin{array}{l}\text { Average number of } \\
\text { living units per } \\
\text { building }\end{array}$ & 6 & & 6 & & 6 & \\
\hline $\begin{array}{l}\text { Number of Single } \\
\text { family houses in } \\
\text { serving area }\end{array}$ & 1200 & & 1000 & & 1000 & \\
\hline $\begin{array}{l}\text { Number of } \\
\text { apartment buildings } \\
\text { in serving area }\end{array}$ & 50 & & 200 & & 225 & \\
\hline $\begin{array}{l}\text { Single family houses } \\
\text { density per } \mathrm{km}^{2}\end{array}$ & 120 & & 100 & & 100 & \\
\hline $\begin{array}{l}\text { Apartment building } \\
\text { density per } \mathrm{km}^{2}\end{array}$ & 5 & & 20 & & 23 & \\
\hline $\begin{array}{l}\text { Number of buikdings } \\
\text { in serving area }\end{array}$ & 1250 & & 1200 & & 1225 & \\
\hline $\begin{array}{l}\text { Service } \\
\text { characteristics }\end{array}$ & & & & & & \\
\hline $\begin{array}{l}\text { Required } \\
\text { downstream } \\
\text { bandwidth }(\mathrm{kbps}) \text { : } \\
\text { Avg data rate } \\
\end{array}$ & 1024 & 5,0 & 1024 & $5,0 \%$ & 1024 & 5,0 \\
\hline $\begin{array}{l}\text { Required upstream } \\
\text { bandwidth (kbps): } \\
\text { Avg data rate }\end{array}$ & 256 & 5,0 & 256 & $5,0 \%$ & 256 & 5,0 \\
\hline $\begin{array}{l}\text { Average throughput } \\
\text { (kbps): Avg capasity } \\
\text { required per subs }\end{array}$ & 1280 & & 1280 & & 1280 & \\
\hline $\begin{array}{l}\text { Expected traffic } \\
\text { demand in the area } \\
\text { (Mbps) }\end{array}$ & 1344 & & 1344 & & 1344 & \\
\hline $\begin{array}{l}\text { Expected traffic } \\
\text { demand in the area } \\
(\mathrm{Mbps}) \text { per } \mathrm{km}^{2}\end{array}$ & 134 & & 134 & & 134 & \\
\hline Qos per customer & & 0,0 & & 0,0 & & 0,0 \\
\hline $\begin{array}{l}\text { one-time activation / } \\
\text { connection fee }(€)\end{array}$ & 20 & $-0,15$ & 20 & $-0,2$ & 20 & $-0,2$ \\
\hline \begin{tabular}{|l|} 
Subscription fee \\
$(€ /$ month $)$
\end{tabular} & 17,5 & 0,0 & 17,5 & 0,0 & 17,5 & 0,0 \\
\hline
\end{tabular}

many users) such as cabinets, optical network units, base stations and cables.

A number of choices, assumptions, and predictions have to be made before proceeding to the techno-economic analysis of a broadband access network. These include the selection of the geographical areas and customer segments to be served, the services to be provided, and the technology to be used to provide the services [8].

\subsection{Processing (Layer 2)}

This section presents the specific input parameters we use for each technology in our Tool. Each table shows the parameters for each technology. These parameters are divided in 3 main groups: Equipment Components; Cable Infrastructure; and Housing. The housing cost is the cost of building any structures required in the outside plant (Cabinets, closures etc) The outside plant corresponds to the part between $\mathrm{CO}$ and Subscriber house. In the cable infrastructure, the percentage of new cable corresponds to the need of new cable required, and the percentage of new conduit parameter considers the underground and aerial lines.

The civil work cost is calculated based on the above parameters (ex: \% of new conduit (Underground/Aerial), etc) and in the DB cost. Cost of the labour required to install the cabling either in underground ducts (buried trenching) or on overhead poles (aerial trenching).

Table 2 show the ADSL specific input parameters used in our tool. For ADSL technology we do not consider any cost parameter for housing, because our model assumes that the copper cable goes directly from the CO to Subscriber. The DSLAM is located in the $\mathrm{CO}$ and the model includes copper regenerators that are placed along the distribution cables.

Next table (Table 3) presents the specific input parameters for VDSL technology.

The VDSL architecture considers for the outside plant, the feeder network (Fibre cable) from the CO to the Remote Terminal (RT) and the distribution network (Copper cable) from the CO to Subscriber. The remote terminals include optical equipment and the DSLAM equipment.

As we can see in Table 4, for the HFC architecture, the model considers that the outside plant is divided in 3 main areas: Feeder (Fibre cable from the HE to the Fibre Node (FN)); Distribution (coaxial cable from the FN to the neighbourhoods; and Drop (coaxial cable from a TAP into the subscriber's home here is attached to terminal equipment). $\mathrm{RF}$ amplifiers are placed along the distribution cables.

Like VDSL and HFC, the outside plant is divided into Feeder, Distribution and Drop (Table 5). The architecture for this technology considers that the outside plant have 2 layers of split (primary and secondary split). For example, if the primary split is $1 \times 4$ and the secondary split $1 \times 8$, then the network splitting ratio (or split scenario) will be 32 . 
Table 2. Adsl Specific Input Parameters

Continued Table3

\begin{tabular}{|l|}
\hline \multicolumn{1}{|c|}{ Specific Input Parameters: ADSL } \\
\hline \multicolumn{1}{|c|}{ DSLAM Line Card (only for Subs not for homes passed) } \\
\hline $\begin{array}{l}\text { Number of port per line card (Max.\# of subscribers per line } \\
\text { card) }\end{array}$ \\
\hline Number of Subs to be supported \\
\hline Total number of DSLAM line cards required (customer side) \\
\hline Downstream Rate (Mbps) per DSLAM line card port \\
\hline Upstream Rate (Mbps) per DSLAM line card port \\
\hline DSLAM Units (Chassis) \\
\hline Number of Line Cards (ATU-Cs) per DSLAM unit: Slots \\
\hline Total number of subscribers per DSLAM unit (chassis) \\
\hline Total number of DSLAM units (Chassis) required \\
\hline Rack \\
\hline Max. Number of DSLAM units installed per rack \\
\hline Total Number of Racks required \\
\hline Copper regenerator (for all homes passed) \\
\hline Distance Between Copper Regenerator (m) \\
\hline Number of regenerator (or active repeater) per Subsc line \\
\hline Splitters \\
\hline Number of Splitter (Subscriber) \\
\hline Number of Splitter (CO)...one splitter per DSLAM unit \\
\hline CPE (only for Subs not for homes passed) \\
\hline \% of CPE cost supported by the operator \\
\hline \multicolumn{1}{c|}{ Cable Infrastructure } \\
\hline Distribution Cable: From DSLAM in the CO to Subscriber \\
\hline Distribution cable type (from Co or RT to Subsc) \\
\hline Average distribution length (m) \\
\hline$\%$ of new cable in Distribution plant \\
\hline$\%$ of new conduit (Underground / Aerial) \\
\hline
\end{tabular}

Table 3. Vdsl Specific Input Parameters

\begin{tabular}{|l|}
\hline \multicolumn{1}{|c|}{ Epecific Inpuipment Components } \\
\hline OLT (only for Subs not for homes passed) \\
\hline $\begin{array}{l}\text { Downstream OLT port capacity (Mbps): 1 port per Remote } \\
\text { Terminal }\end{array}$ \\
\hline $\begin{array}{l}\text { Upstream OLT port capacity (Mbps): 1 port per Remote } \\
\text { Terminal }\end{array}$ \\
\hline Remote Terminal (only for Subs not for homes passed) \\
\hline Max. Number of subscribers per Remote Terminal \\
\hline Number of subscribers per Remote Terminal (Homes/Fiber) \\
\hline Number of RT required \\
\hline Remote DSLAM equipment \\
\hline Number of DSLAMs required \\
\hline DSLAM Line Card (only for Subs not for homes passed) \\
\hline $\begin{array}{l}\text { Number of port per line card (Max.\# of subscribers per line } \\
\text { card) }\end{array}$ \\
\hline Number of Subs to be supported by each RT DSLAM \\
\hline Total number of DSLAM line cards required (customer side) \\
\hline Downstream Rate (Mbps) per DSLAM line card port \\
\hline Upstream Rate (Mbps) per DSLAM line card port \\
\hline
\end{tabular}

\begin{tabular}{|l|}
\hline DSLAM Units (Chassis) \\
\hline Number of Line Cards (ATU-Cs) per DSLAM unit: Slots \\
\hline Max. number of subscribers per DSLAM unit (chassis) \\
\hline Total number of DSLAM units (Chassis) required \\
\hline Rack \\
\hline Max. Number of DSLAM units installed per rack \\
\hline Total Number of Racks required \\
\hline Optical repeater and Copper regenerator (for all HP) \\
\hline Distance between Optical Repeater (m): Feeder Plant \\
\hline Number of Optical Repeater per feeder cable \\
\hline Distance Between Copper Regenerator (m): Distribution plant \\
\hline Number of regenerator (or active repeater) per Sub line \\
\hline Splitters \\
\hline Number of Splitter (Subscriber) \\
\hline Number of Splitter (CO)...one splitter per DSLAM unit \\
\hline CPE (only for Subs not for homes passed) \\
\hline \% of CPE cost supported by the operator \\
\hline \multicolumn{1}{|c|}{ Cable Infrastructure } \\
\hline Feeder cable: From CO to DSLAM in the Remote Terminal \\
\hline Feeder cable type (from CO to RT) \\
\hline Average feeder length (m) \\
\hline \% of new cable in Feeder plant \\
\hline \% of new conduit (Underground / Aerial) \\
\hline Distribution Cable: From DSLAM in the RT to Subscriber \\
\hline Distribution cable type (from Co or RT to Subsc) \\
\hline Average distribution length (m) \\
\hline \% of new cable in Distribution plant \\
\hline \% of new conduit (Underground / Aerial) \\
\hline \\
\hline Closures/Cabinets for RT (for all homes passed) \\
\hline$\%$ of new cabinets/closures \\
\hline
\end{tabular}

Table 4. HFC Specific Input Parameters

\begin{tabular}{|l|}
\hline Specific Input Parameters: HFC \\
\hline \multicolumn{1}{|c|}{ Equipment Components } \\
\hline $\begin{array}{l}\text { Head End: CMTS and OLT (only for Subs not for homes } \\
\text { passed) }\end{array}$ \\
\hline Max number of subscribers support by CMTS \\
\hline Downstream OLT port capacity (Mbps): 1 port per Fiber Node \\
\hline Upstream OLT port capacity (Mbps): 1 port per Fiber Node \\
\hline Fiber Nodes (only for Subs not for homes passed) \\
\hline Max. Number of subscribers per fiber node (Homes/Fiber) \\
\hline Number of subscribers per fiber node (Homes/Fiber) \\
\hline RF amp, TAPs and coupler ( for all homes passed) \\
\hline Distance between Optical Repeater (m): Feeder Plant \\
\hline Distance Between RF Amplifiers (2-way): Distribution plant \\
\hline Number of Drops per TAP \\
\hline Number of Splitter / Coupler per distribution network \\
\hline CPE (only for Subs not for homes passed) \\
\hline \% of CPE cost supported by the operator \\
\hline
\end{tabular}




\begin{tabular}{|l|}
\hline \multicolumn{1}{|c|}{ Cable Infrastructure } \\
\hline Feeder cable (trunk) \\
\hline Feeder cable type \\
\hline Average feeder length (m) \\
\hline$\%$ of new cable in Feeder plant \\
\hline$\%$ of new conduit (Underground / Aerial) \\
\hline Distribution Cable \\
\hline Distribution cable type \\
\hline Average distribution length (m) \\
\hline Average distribution networks per Fiber Node \\
\hline$\%$ of new cable in Distribution plant \\
\hline$\%$ of new conduit (Underground / Aerial) \\
\hline Drop Cable \\
\hline Drop cable type \\
\hline Average drop length (m) \\
\hline$\%$ of new cable in Drop plant \\
\hline$\%$ of new conduit (Underground / Aerial) \\
\hline \\
\hline Housing: FN closures for all homes passed \\
\hline$\%$ of new cabinets/closure \\
\hline
\end{tabular}

\begin{tabular}{|l|}
\hline Distribution Cable \\
\hline Distribution cable type \\
\hline Average distribution length (m) \\
\hline \% of new cable in Distribution plant \\
\hline \% of new conduit (Underground) \\
\hline Drop Cable \\
\hline Drop Cable type \\
\hline Average drop length (m) \\
\hline \% of new cable in Drop plant \\
\hline \% of new conduit (Underground) \\
\hline Total Network Distance from OLT to ONU/T (km) \\
\hline \multicolumn{1}{|c|}{ Housing } \\
\hline Housing (Splitter cabinets) \\
\hline \% of new Splitter / ONU closures \\
\hline
\end{tabular}

Table 6. PLC Specific Input Parameters

\begin{tabular}{|r|}
\hline Specific Input Parameters: PLC \\
Equipment Components
\end{tabular}

LV Transformer equipment for all homes passed (Head end)

Number of MV/LV transformers per Transformer Substation AVG Number of feeders per MV/LV transformer

Table 5. FTTx Specific Input Parameters

Specific Input Parameters: FTTH: PON / FTTC / FTTCab Equipment Components

OLT (only for Subs not for homes passed)

Downstream Rate (Mbps) per OLT

Upstream Rate (Mbps) per OLT

ONU's

Max. Number of ONUs per Network Total ONUs

OLT's

Total of OLTs (OLTs ports): Homes Passed

Total of OLTs (OLTs ports): Subscribers

Splitters

\# 1 x 4 Splitters

\# 1 x 8 Splitters

\# 1 x 16 Splitters

\# 1 × 32 Splitters

\section{Split Ratios}

Primary Split (Feeder)

Secondary Split (Distribution)

Network level splitting ratio (Split Scenario)

CPE (only for Subs not for homes passed)

$\%$ of CPE cost supported by the operator

Cable Infrastructure

\section{Feeder cable}

Feeder cable type

Average feeder length (m)

$\%$ of new cable in Feeder plant

$\%$ of new conduit (Underground)
Downstream LV TE capacity (Mbps)

Upstream LV TE capacity (Mbps)

Max Number of subscribers per LV Transformer

AVG Number HH per MV/LV transformer: \# Customers per LV network

Number of LV networks required (LV transformers)

PLC Repeater for all LV networks (all homes passed)

Maximum repeaters reach (m): Max. distance to LV transformer or between

Number of PLC repeaters per LV feeders

Average number of repeaters in Single house

Average number of repeaters in building (repeater in the meter room)

Couplers (one coupling unit included in LV transformer)

Number of coupling units per LV Transformer

CPE (only for Subs not for HP)

$\%$ of CPE cost supported by the operator

Cable Infrastructure

\section{Cable type}

Average feeder length (m): length of feeders

$\%$ of new cable

$\%$ of new conduit (underground/aerial) 
This means that a single feeder network supports 32 subscribers.

The PLC architecture considers that the PLC Injection Point is the MV/LV transformer equipment (LV Head End) (Table 6). The low voltage cables are the medium of transmission and required repeaters for maintaining the signal quality. The coupling unit is installed in the LV transformer station (MV/LV transformer: pole or ground).

In the WiMAX technology (Table 7), the model divides the equipment components into BS equipment and $\mathrm{CPE}$ equipment. The model assumes that a BS have several sectors. For each sector, a radio transceiver module and a sector antenna is also required.

For the wireless technologies we replace the cable infrastructure parameters by coverage parameters. The housing cost is based in the percentage of BS needing new sites.

Next figure (Fig 4) shows one of the schemes produced, and represents the architecture and components of the VDSL technology.

The outputs calculated are: Subscriber costs; ARPU: Average Revenue Per User; Cost per subscriber; Cost per home passed; Mbit cost; OAM costs; Installation cost; Net Present Value (NPV); Internal Rate of Return (IRR); Payback Period; Revenues; Investments; Life Cycle Cost; Cash balance.

\section{Conclusion}

This paper presents a model framework and identifies all the essential costs of building access networks for 7 broadband access technologies.

The work identifies 3 main important layers: introduction of the general input parameters (Layer 1- Scenario definition); introduction of the Specific parameters for each technology, and the $\mathrm{db}$ access (Layer 2); and the outputs production (Layer 3). This paper focuses on the identification of the Specific Input Parameters because we consider one of the most important keys for the successful deployment of our tool.

The proposal tool performs a detailed comparison of the different broadband access technologies in several scenarios. Different market segments (Scenarios) have different geographical characteristics and will require different amounts of access bandwidth. These different market segments will be served by alternative access technologies that minimise overall costs. To measure the attractiveness of the several broadband access technologies, the proposal tool compares the costs, revenues, NPV, IRR, payback periods etc for the 3 scenarios along 10 periods.
Table 7. WiMAX Specific Input Parameters

\begin{tabular}{|l|}
\hline Specific Input Parameters: WiMAX \\
\hline \multicolumn{1}{|c|}{ Equipment } \\
\hline Base Station \\
\hline Downstream Sector capacity (Mbps) \\
\hline Upstream Sector capacity (Mbps) \\
\hline Maximum sector throughput (Mbps): Capacity per sector \\
\hline Maximum sectors per base station \\
\hline Maximum BS throughput (Mbps): Capacity per BS \\
\hline Base Station range (m): Max. Distance between BS and Sub \\
\hline Maximum Coverage per BS (Km²) \\
\hline Maximum \# of subscribers connected to a single BS \\
\hline Number of Subsc per BS \\
\hline Maximum \# of subscribers connected to a single sector \\
\hline Number of sectors required to 1050 Subs \\
\hline Number of BS required \\
\hline Geographical Area Covered by BS (Km ${ }^{2}$ ) \\
\hline CPE (only for Subs not for homes passed) \\
\hline$\%$ of Indoor CPE \\
\hline \% of Outdoor CPE \\
\hline$\%$ of CPE cost suported by the service provider \\
\hline \\
\hline Geographical Area to be Covered (Km): Perimeter \\
\hline Geographical Area to be Covered (Km $\left.{ }^{2}\right)$ \\
\hline Distance between BS and Subs (m) \\
\hline Geographical Area Covered (km ${ }^{2}$ ) \\
\hline \\
\hline of BS needing new sites \\
\hline
\end{tabular}

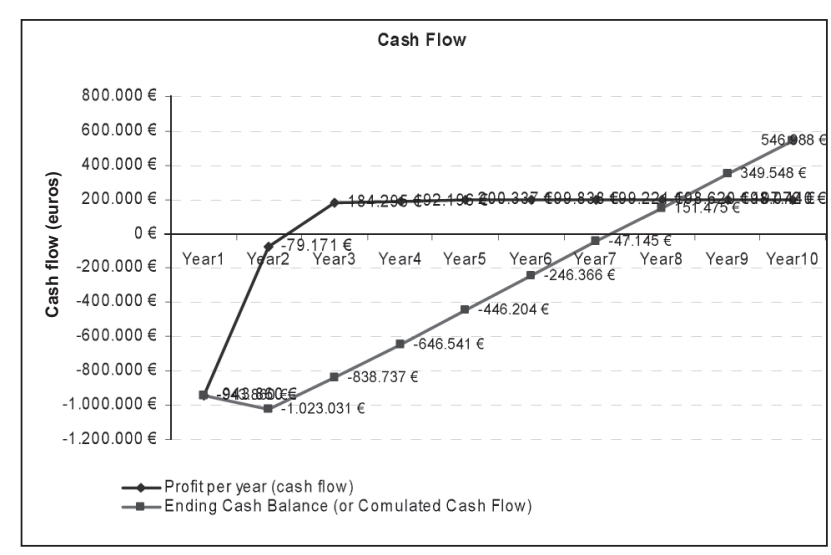

Fig 3. Outputs: Graphics

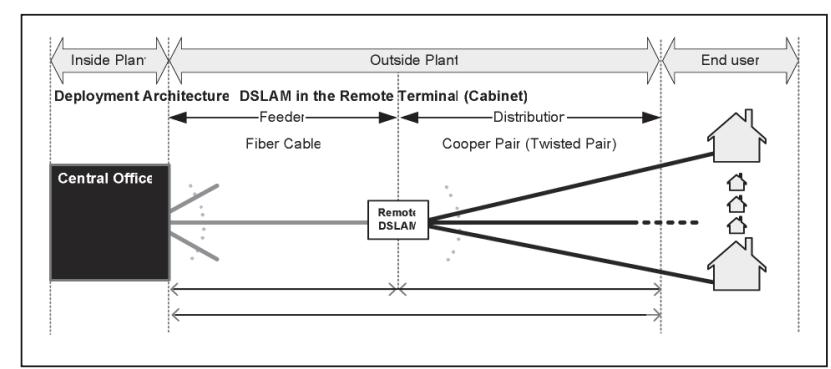

Fig 4. Outputs: Schemes 


\section{References}

1. TARDY, I.; BRÅTEN, L.; BICHOT, G.; SETTEMBRE, M.; SESEŃA, J. Hybrid architecture to achieve true broadband access in rural areas. In Proc of BroadBand Europe, 8-10, Dec 2004, p. 1-6.

2. BOSCHER, C.; HILL, N.; LAINE, P.; CANDIDO, A. Providing always-on broadband access to under-served areas. In Alcatel Telecommunications Review, 2007, 4th Quarter 2003/ 1st Quarter 2004, p. 127-132.

3. IMS, L. A.; BHATNAGAR; A.; ØSTLYNGEN, E.; BOZORGEBRAHIMI, K. Towards the next generation broadband network platform. Telektronikk, 2004, 4, p. 107125

4. GALPERIN, H. Wireless networks and rural development: opportunities for Latin America. Information Technologies and International Development, 2005, 2(3), p. 47-56.
5. FRANCE, P. W.; SPIRIT, D. M. ; WHITT, S. Developing the access network. BT Technology Journal, Oct. 1998, 16 (4), p. 9-20.

6. IMS, L. A.; MYHRE, D.; OLSEN, B. T. Broadband capacity upgrade strategies in residential areas: an investment cost analysis. European Transactions on Telecommunications, March 2001, 12(2), p. 105-113.

7. PEREIRA, J. P.; PIRES, J. A. Broadband technologies and the access network. In Proc of $7^{\circ}$ CAPSI, Aveiro, Portugal, 17-19 Jan 2007, p. 50-60.

8. SMURA, T. Competitive potential of WiMAX in the broadband access market: a techno-economic analysis. Master of Science in Technology, Helsinki University of Technology. Helsinki, 2006. 124 p.

\section{PLAČIAJUOSČIO RYŠIO TECHNOLOGIJU IVERTINIMO PRIEMONE்}

\section{J. P. R. Pereira, J. A. Pires}

Santrauka

Šio straipsnio tikslas - nustatyti visas svarbiausias plačiajuosčio ryšio tinklo įrengimo išlaidas ir palyginti ịvairius skirtingų technologiju scenarijus. Ivairūs rinkos segmentai (scenarijai) turi skirtingas geografines charakteristikas ir reikalauja skirtingo dydžio ryšio juostos pločio. Šie skirtingi rinkos segmentai bus aptarnaujami alternatyvių ryšio technologijų, kurios minimizuoja bendrąsias sąnaudas. Norint tai atlikti, buvo sukurtas modelis ir įvertinimo priemonè.

Siekiant nustatyti kelių plačiajuosčio ryšio technologijų patrauklumą, pasiūlyta priemonė palyginti trijų scenarijų sąnaudas, pajamas, atsipirkimo laiką ir kita. Straipsnyje pateikiama aštuonių plačiajuosčio ryšio technologijų technoekonominè analizè.

Reikšminiai žodžiai: ryšio tinklai, plačiajuosčio ryšio technologijos, sąnaudų modelis.

João Paulo Ribeiro PEREIRA. Professor of Informatics and Communications, Dept of Management and Technological School of Polytechnic Institute of Bragança.

Graduation: Business Informatics at ISLA (1995). Master: Business Informatics at University of Minho (1999). PhD student: Instituto Superior Técnico, Technical University of Lisbon (since 2003). Author of about 12 research articles.

Research interests: information systems, broadband access technologies and innovation systems.

José Adriano Gomes PIRES. PhD in Computer Science, University of Minho (2001). Professor Coordinator at Dept of Informatics and Communication, High School of Technology and Management, Polytechnic of Bragança. Pro-Rector of Polytechnic of Bragança. Research interests: E-commerce, information systems, data base system. 